\title{
マン・スケジューリングにおけるタブー探索法の適用性*
}

\section{Adaptability of Tabu Search in Man Scheduling Problem*}

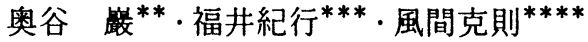 \\ By Iwao OKUTANI ${ }^{* *} \cdot$ Noriyuki FUKUI ${ }^{* * *} \cdot$ Katunori KAZAMA ${ }^{* * * *}$
}

\section{1.まえがき}

先行後続関係を持つ複数の作業が 1 つのプロジェ クトを構成しているものとしたとき，プロジェクト の納期と使用可能な資源（作業員や機械）の制限の もとで，経済效率的に望ましい各作業の開始時刻を 求める問題をマン・スケジューリング問題というが 時間をたとえば日単位といった離散時点で区切って 扱かうと，典型的な組み合わせ問題となり，効率的 な求解は一般には困難とされている。

この問題に対して，近年各方面で応用が盛んな遺 伝的アルゴリズム（Genetic Algorithm, GA）を適用 した解法については既に報告した" 。この方法の最 大の特徵は計画目標を複数目標として設定できると いう柔軟性にあり，この点が単一目標しか扱うこと ができない従来法とは大きく異なっている。

本研究は, マン・スケジューリング問題に対して 一般にGAに比べて局所探索性能が高いとされている タブー探索法（Tabu search algorithm, TABU） ${ }^{2)}$ 適用した方法について検討するものであるが，この 方法に损いても計画目標は複数目標を指向する。し たがって，具体的な計算例におけるアルゴリズムの 性能評価はGAによる方法との比較対比をとおして行 っている。

\section{2 . 問 題 の 設 定}

スケジュールを表現するネットワークはノードを

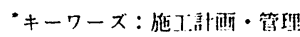

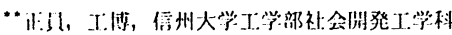

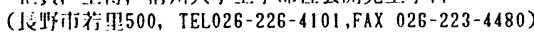

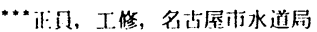

(名古屋术中区三の丸, TEL 052-62-6161,FAX 052-622-5941)

…非会及，信州大学:学部社会明発工学科

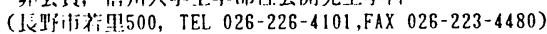

作業に，アークを作業の先行後続関係に対応させた 有向グラフで表わすものとし，ノードには作業番号 i（i=0,1，․,n）を与えておく。ただし，始端ノ一 ド0と終端ノードnはダミーである。プロジェクト を構成する作業の技術的順序関係が与えられればこ うしたネットワークは容易に棈築することができる が，これを初期ネットワークとよぶことにする。な お，ここでは簡単のために単一資源の問題を扱かう。

さて，作業iの必要資源量a，と処理時間biを与え PERT計算により初期ネットワークに対する作業iの 最早開始時刻 $t^{\mathrm{E}} \mathrm{i}$ を求める ${ }^{3)}$ 。初期スケジュール として各作業を最早開始時刻に開始するスケジュー ルを考えると, そのスケジュールのもとでのプロジ エクト完了時刻 $\mathrm{T}_{\mathrm{m} \text { in }}$ が求められるし，いわゆる山積 み図を描くことで，初期スケジュールに対する最大 投入資源量 ${ }^{*}$ が求められる。

以上のような準備のもとに，われわれはここで扱 かう問題を次のように設定する。すなわち，まず納 期 $\mathrm{T}_{\mathrm{max}}$ と投入可能資源総量 $\mathrm{R}_{\mathrm{max}}$ を与える。 $\mathrm{T}_{\mathrm{m}} \mathrm{n} \times$ は Tminを下回らない範围で技術的判断によって与えれ ばよいし， R $\mathrm{max}$ は経済的判断に実行可能性の判断 を加味して，たとえばR* 前後の值として与えれば よい。そうすると，問題は「投入資源を $R_{\max }$ 以内に 抑え，かつプロジェクトをTmax以内完了するとい う条件のもとに，与えられた計画目標を最適化する スケジュールを求める」と記述できる。ここに，ス ケジュールを求めるということは，具体的には各作 業の開始時刻 納期 $\mathrm{m}$ maxが与えられた段階で最遅開始時刻 $\mathrm{t}^{\mathrm{i}}$ iを求 めたとき，計画目標が改善されるよう $\left[t^{\mathrm{E}}{ }^{\mathrm{i}}, \mathrm{t}^{\mathrm{L}}{ }^{\mathrm{i}}\right]$ の範囲で $t_{i}$ の值を定めるということである。

スケジュールの計画目標としては，プロジェクト 完了時刻Tの最小化，最大投入資源量R（時刻kの投 入資源量を $R_{\mathrm{k}}$ としたとき，その最大値）の最小化， 
遊休資源を少なくするための平滑度 $S\left(=\sum R^{2}{ }_{k}\right)$ の 最小化あるいは次式で与えられる資源使用効率Eの 最大化が考えられる。

$\mathrm{E}=\sum_{\mathrm{i}} \mathrm{a}_{i} \mathrm{~b}_{\mathrm{i}} / \mathrm{TR}$

こうした複数の目標を同時に考慮する簡単な方法の 1つとして線形結合による和を考える方法があるが ここでもその方法を採用する。Eを除く目標は無次 元ではないので，まずそれらを次のような方法で無 次元化し，fiという1以下の非負数に変換する。

\section{$f_{i}=\frac{Y_{\max }-Y}{Y_{\max }-Y_{\min }} \quad(i=1,2,3)$}

ここに，Yはi $\mathrm{i}=1,2,3$ の順にT, R, Sの値をとるものと

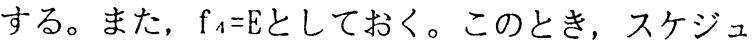
ールの目標兵を

$$
F=\sum_{i=1}^{4} \alpha_{i} F_{i}
$$

とし，この最大化を図る。ただし， $\alpha$ iは和が1と なる各目標のウェイトである。

\section{TABUの適用法}

\section{（1）TABU 探索法}

TABU探索法は最近提案された方法で，各種組み合 わせ問題を中心に適用例が報告されている この最適化アルゴリズムは，探索過程におけるある 1点からたとえ改悪であっても最良の近傍解に移動 すること及び1度通った点を記憶しておいてその点 への再㷌を禁止することの2点に特幑があるが，後 者の性質がタブーという独特の名前に繫っている。 禁止条件は一般にタブーリストとよばれるところに 記憶されるが，リストサイズと称する容量を設けて おいて，禁止条件を適当な時間後に忘却するように し，探索範囲が不必要に狭められないように工夫し ている。

\section{（２）スケジュールのビット列表現"}

初期スケジュールは，すべての作業を最早開始時 刻に開始させるようにしているため，Tの最小化と いう目標以外は無視された形となる。したがって， ここでは技術的な順序関係がない作業間に人為的な 先行後続関係を生成させ，作業開始時刻を先送りす
ることによって計画目標の向上を困る。

いま，作業 $\mathrm{i}, \mathrm{j}$ 間に技術的順序関係がないものと し，そこにたとえば作業iを作業jに先行させるとい う関係を発生させるとしよう。このことは初期ネ: トワークに対して，i $\rightarrow \mathrm{j}$ のアークを 1 本追加する ことに他ならない。このことを次の記号 $\delta_{\mathrm{i} j} \mathrm{j}$

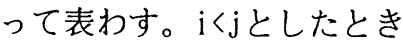

$$
\begin{aligned}
& \delta_{\mathrm{i}} \mathrm{j}=\left\{\begin{array}{l}
1: \mathrm{i} \rightarrow \mathrm{j} \text { のアークを追加 } \\
-1: \mathrm{j} \rightarrow \mathrm{i} \text { のアークを追加 } \\
0: \mathrm{i} \text { とを結合せず }
\end{array}\right. \\
& \text { ところで, } \mathrm{i}, \quad \mathrm{j} \text { 新たなアークで結合したとき }
\end{aligned}
$$

となると，作業 $\mathrm{j}$ 最遅開始時刻以前に始めること が不可能となるし，

$$
\mathrm{t}^{\mathrm{L}}{ }_{\mathrm{i}}+\mathrm{b} \mathrm{i}_{\mathrm{i}} \leqq \mathrm{t}^{\mathrm{E}}{ }_{\mathrm{j}}
$$

となっていれば, 作業jの先送りが不要となりアー クの存在は無意味となる。

したがって(3)式または(4)式が成立する場合にけ $\delta_{i j}=1$ を除外し，（3）式および(4)式でi，jを入れ替 えた式を(3)'式，(4)'式としたとき，そのいずれか 一方が成立する場合には $\delta_{i j}=-1$ を除外して考える 必要がある。また，(3)式と (4)'式がともに成立す るか（3）'式と(4)式がともに成立する場合には， $\delta_{\mathrm{i} j}$ そのものを除いて考えなければならない。

このような検討を技術的順序関係がないすべての ノード間で行うことにより，アークを追加し得るノ 一ドペアー（i，j）と当該追加アークの性質を表わす $\delta i_{j}$ の取り得る值が決定される。 $\delta i_{j}$ の値を 1 つの ルールのもとに与え，それを適当に並べたいわゆる

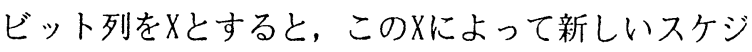
ュールが表現されることになる。

\section{( 3 ） スワップ操作}

図-1に示した小規模プロジェクトを表わすネット ワークを例に説明する。実線で示したアークは技術 的順序関係を表わしているが，(2)で述べた方法に よりビット列の要素を選んでゆくと

$\mathrm{X}=\left(\delta_{14}, \delta_{15}, \delta_{14}, \delta_{24}, \delta_{25}, \delta_{26}, \delta_{34}, \delta_{35}, \delta_{45}, \delta_{56}\right)$ となる。ここに, $\delta_{14}, \delta_{15}, \delta_{16} \delta_{26}, \delta_{56}$ は-1の 值を， $\delta_{31}$ は1の値をそれぞれ取らない。図一1の破 線のアークを初期ネットワークに付加した新たなス ケジュールは 


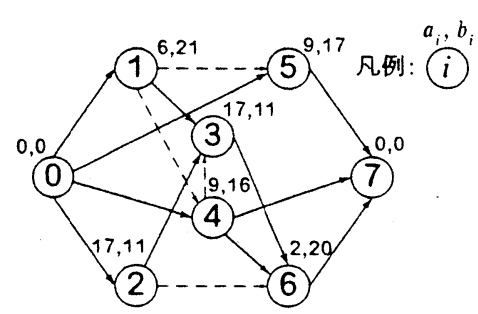

図-1 小ネットワーク

$X=(1,1,0,0,0,1,-1,0,0,0)$

のように書き表わされるが，この点（ビット列）の 近傍解を求める操作を文献4）に倣ってスワップ 操作とよぶことにする。

\section{a ）スワップ 1}

スワップ操作の 1 つの方法として，Xの任意の部 分列 $\mathrm{g}$ の記号の順序を入れ換えるという方法が考 えられる7)。しかしながら，単純な順序の入れ換え だけでは， $\delta i j$ のとり得ない値を与えるという不合 理も発生するので, そうした場合には当該 $\delta i j$ の値 を听するという約束をしておく。例えば，(5)式で 与えられるビット列 Xの第 4 要素から第 7 要素の部 分列gに対して行うスワップ操作を $\operatorname{Swap} 1(4,7)$ とし たとき，操作前後のビット列は図-2(a)のようにな る。スワップ操作後のネットワークの変化を具体的 に記すと次のようになる。いまノードiからノード jに向かうアークをアーク（i，j)のように表わすもの としたとき

$$
\begin{aligned}
& \text { アーク }(2,4) \text { なし } \rightarrow \text { 新しいアーク }(4,2) \text { の生成 } \\
& \text { アーク }(2,5) \text { なし } \rightarrow \text { 新しいアーク }(2,5) \text { の生成 } \\
& \text { アーク }(2,6) \rightarrow \text { 消滅 }(\text { アークの除去) } \\
& \text { アーク }(4,3) \rightarrow \text { 消滅(アークの除去) }
\end{aligned}
$$

なお，gの順序の入れ換えによっても元のgと変わら ないときは，当該スワップ操作は無意味であり実行 しないものとする。

このようなスワップ操作をここではスワップ1と よぶ。

\section{b ） スワップ 2}

第2番目のスワップ操作（スワップ2）として，部 分列gの各要素を一定の確率で別の値にするという 方法が考えられる。いま，各要素を元の值のままに 保持する確率を $\mathrm{r}$ したとき要素の変化し得る值が 1つの場合は (1-r)の確率で, 2つの場合は (1-r)/2の 確率で別の値に切り変えればよい。(5)式のビット 列Xのスワップ1 と同じ部分列gに対して行う操作を

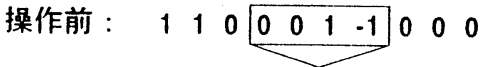 \\ 操作後： $1100-11000000$}

(a) $\operatorname{Swap1}(4,7)$

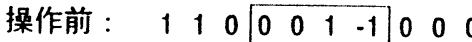

操作後： $11100 \begin{array}{cccccccc}1 & -1 & 0 & 0 & 0 & 0 & 0\end{array}$

(b) $\operatorname{Swap2}(4,7)$

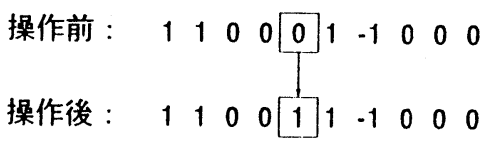

(c) Swap3

図-23種類のスワップ操作の模式図

Swap2 (4, 7)のように表わすものとしたとき，操作前 後のビット列は図-2(b)のようになる。図の例では 部分列の要素はすべて別の值に切り変わっているが， 近傍探索というスワップ操作の本来の目的からすれ ばrの值は大きめに設定し，gの要素の変化を低く抑 えるのが妥当であろう。

ところで，スワップ1，スワップ2ともに部分列 のとり方を規定しておく必要があるが，ここでは次 のような方法を採用した。すなわち近傍探索という スワップ操作本来の目的を逸脱しないようにし，か つ部分列の変更という操作の意味を損なわないよう にするため, $\mathrm{g}$ の次元数 $\mathrm{n}_{\mathrm{g}}$ に対して

$$
2 \leqq \mathrm{n}_{\mathrm{g}} \leqq \mathrm{Nq}
$$

なる制約を付しておき，この範囲の中で $\mathrm{g}$ のきさ をランダムに与えるようにする。ここに，Nはビッ ト列Xの次元数，qは1未満の正の定数である。この ようにして決められる部分列をXの左端から順次と ってゆき，最終的にはXのビット列全体が部分列で 被覆されるようにする。たとえば，Xがh個の部分列 $\mathrm{g}_{\mathrm{i}}(\mathrm{i}=1 \sim \mathrm{h})$ で覆われる場合

$$
X=\left(g_{1}, g_{2}, \cdots, g_{h}\right)
$$

となる。

\section{c ）スワップ 3}

第3番目のスワップ操作（スワップ3）として，X の要素 1 つのみを別の值に変化させるという方法を 考える。これはスワップ2で $n_{\mathrm{g}}=1, \mathrm{r}=0$ とおいた特殊 な場合であるとも解釈できる。 
図ー2(c)に(5)式のXの第5要素を0から1に変化さ せるスワップ操作を示したが, 本スワップでは同じ 第5要素を0から-1に変化させる操作は, 計算過程の 中では別のスワップとして扱う。

以上，3つのスワップ操作について述べたが，ス ワップ1はトラベリングセールスマン問題における スワップ操作 ${ }^{1)}$ を模してはいるものの, 物理的意味 合いは薄い。スワップ2は部分列 $\mathrm{g}$ の次元数が大きく， rが小さいと（要素を変化させる確率が大きいと）, 1回のスワップ操作でスケジュールは元のスケジュ 一ルからかなり離れてしまう可能性があり近傍探索 の目的を遂行できなくなる恐れがある。最後のスワ ップ3は, 最も近傍解の概念に近い解を探索すると 思われるが, 探索効率の点で若干弱さを持っている。

\section{(4) タブーリスト}

スワップ1,2では部分列の変化で近傍探索を実行 しょうとしていることを考え，いまから新たにスワ ップ操作を行おうとする部分列の中に，既に值を変 化させた要素が含まれていればその部分列を禁止す るという方法をとる。したがって，タブーリストの 中味は変化させた要素の番号 (Xの左端の要素から $1,2, \cdots$ ‥人う付したもの）とすれば十分である。 スワップ3については一旦その値を変化させた要素 が元の値に戻ることを禁止するという方法をとるこ ととし, タブーリストは値を変化させた要素番号と 要素の元の值で構成するようにする。

なお，タブーリストにはそこに含めることのでき る要素数の上限（=タブーリスト・サイズし）を設 けておく。要素数が上限に達している状態で新たに 禁止すべき要素が現れた場合にはリストに組み入れ た順番の古いものから消去してゆくようにする。

\section{（5）計算手順}

\section{全体的な計算の流れは}

(1)与えられたプロジェクトに対し，ランダムなビ ット列を複数個（K個）発生させる。

(2)それぞれのビット列を出発点として近傍探索を 所与の回数 (M回) 繰り返えし局所最適解を求 める。

(3)複数の局所最適解のうち最大の目標関数値を与. えるスケジュールを最適解とする。
である。この中でランダムなビット列の発生につい ては具体的には次のような方法を採る。初期スケジ ユールは工期の点で有利性を持っていることを考え ると, ビット列X中の要素 $\delta \mathrm{i}$ 值の与え方として, その取り得る値を均等確率で割り振ることは得策で はない。つまり，Xの中に1や-1が多く含まれるよう になれば，対応ノード間にアークが付加され，その 都度関連作業の開始時刻が先送りされる可能性が高 まって, 結局, 出発点となるスケジュールは既に工 期の点でかなり不利な状態になっていることが考え

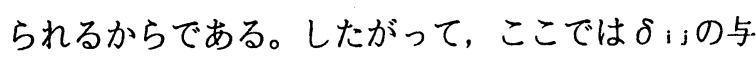
え方として0を取る確率を $\mathrm{p}(》 0)$ ，それ以外の值を 取る確率を(1-p) (0以外の值が2つあれば均等確率で 与える)として，乱数を用いて決定することとした。

以上のような準備のもとに，タブー探索法を用い た計算手順を示すが，スワップ操作の種類によらな い共通的なアルゴリズム記述を期すため，スワップ 3は1つの要素から成る部分列 $\mathrm{g}$ 変化としてとらえ る。

〈Step0〉繰り返し回数K, Mおよびタブーリストサ イズLを与える。 $\mathrm{F}_{\mathrm{nest}}^{*}=-1.0, \mathrm{k}=1$ とおく。

〈Step1〉ランダムなビット列Xを発生させ, PER T計算と山積み計算を行ってFを求める。タブ一 リストを空にし， m=1, F best 〈Step2〉Xから部分列gを1つ取り出す。

〈Step3〉部分列gにスワップ操作を施したとき

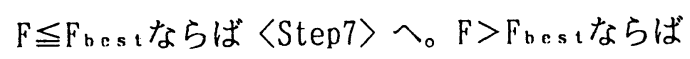
次のStepへ。

〈Step4〉当該スワップを実行したとき、タブー を犯すならば〈Step6〉へ。そうでなければ次 のStepへ。

〈Step5〉 $\mathrm{g}^{*}=\mathrm{g}$ とし，gにスワップ操作を施したも

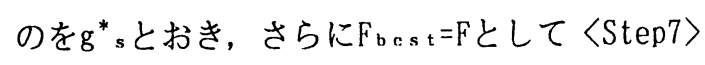

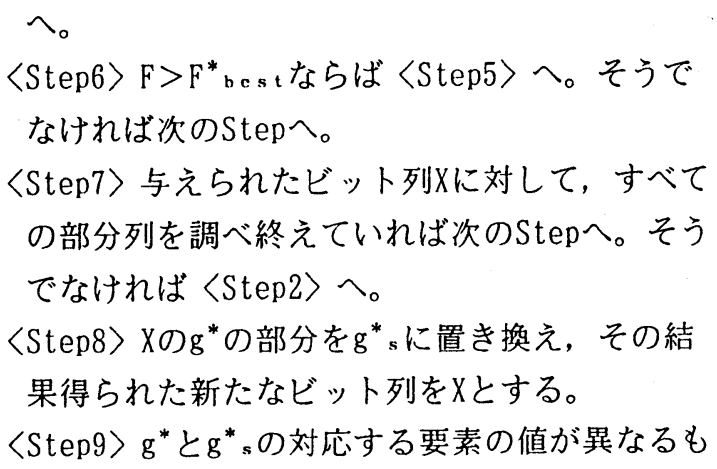


のを取り出し，その要素をタブーリストに入れ る。このとき，既にリスト中に記録されている 要素と合わせて，その個数が乚を上回われば， より記録時点の古い要素を消去し，リスト中の 要素数をL個にする。

〈Step10〉 $\left.\mathrm{F}_{\mathrm{best}}\right\rangle \mathrm{F}_{\mathrm{best}}^{*}$ ならばF*ast $\mathrm{F}_{\mathrm{best}}$, $X^{*}=X$ とおいて次のStepへ。そうでなければ何も せずに次のStepへ。

〈Step11〉m〈Mならばm: $=m+1$ として〈Step2〉へ。 $\mathrm{m}=\mathrm{M}$ ならば次のStepへ。

$\langle$ Step12〉 $\mathrm{k}\langle\mathrm{K} な ら は ゙ k:=\mathrm{k}+1$ として〈Step1〉へ。 $\mathrm{k}=\mathrm{K}$ ならばX*を最良スケジュールとして計算終 了。

\section{4．計算例による有効性の検討}

\section{(1) 予備的実験}

実際に計算を行うにあったては，割合または確率 $\mathrm{q}, \mathrm{r}, \mathrm{p}$ の值およびL, K, Mの值を何らかの方法で与える 必要があるが，ここでは試行錯誤法によってそれら の値を 1 つずつ決めてゆく。後のGAとの有効性比較 においては，ノード数8〜70のネットワークを対象 としていることを考え, 中間的大きさのノード数 38のネットワークを予備検討の主たる対象として具 体的な実験を実行する。当該ネットワークを含め本 研究では実験対象となるプロジェクトはすべて計算 機の中で生成（各作業の処理時間，必要資源量，作 業間の技術的順序関係を乱数を用いて決定）すると いう方法を採っている。なお，目標関数 $\mathrm{F}$ 決める ウェイト $\alpha_{1} \sim \alpha_{4}$ はそれぞれ0.3，0.4，0.3，0とした。

a ） qの決定

スワップ1,2における部分列 $\mathrm{g}$ の大ささ上限を規 定するqの决定にあたっては， $r=0.5, p=0.99, \mathrm{~L}=0.1$ $N$ (整数)， $K=5, M=30$ と置き， $q=0.01 \sim 0.1$ の範囲で 0.01 きざみに変化させるという実験を行った。スワ ップ1では0.05, スワップ2では0.01が最良值である という結果が得られたが，スワップ2における0.01 という值は，ノード数30以下のネットワークである と $n_{k}$ としてほぼ下限值2を与えてしまうという值で あり，スワップ3との対比で考えた計算速度の優位 性を弱める結果にも繫がりかねない。したがって， ここではスワップ2についても敢えてスワップ1と同
じ 0.05を採用することとしたが，このことによる目 標関数Fの最大値の低下は $3 \%$ 程度に止まった。

b ） $\mathrm{r}$ の決定

スワップ2の部分列の要素を元の値のままに保つ 確率 $r に つ い て は ， q=0.05$, その他の条件はa)と同じ

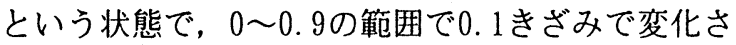
せてみた結果, $r=0.8$ のきに目標関数が最も改善 された。したがって，ここではこの值を值とし て固定することとした。

\section{c ） pの決定}

先にも述べたように，初期スケジュールを表わす ネットワークにあまり多くのアークを付加しない形 で，計算の出発点となるネットワークを与えるため

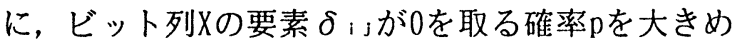
の值にしておく必要がある。 $r=0.8$, それ以外はb)と 同じ条件に保ち， $\mathrm{p} \geqq 0.8$ 範囲で実験を行ってみた 結果, スワップ1では $\mathrm{p}=0.9$ が, 他のスワップではp $=0.99$ 最も良好な結果をもたらすことがわかった。 したがって，以下ではこれらの值を採用することと した。

d ）タブーリストサイズしの決定

$\mathrm{q}, \mathrm{r}, \mathrm{p}$ の値は上で決定された值に固定し， $\mathrm{K}=5, \mathrm{M}=$ 30 として, タブーリストサイズ決定のための実験を 種々行ってみた。スワップ1,2の場合は, 1回のスワ ップ操作ごとに複数の要素がタブーリストに入って くる可能性があるため, 調べるべきしの上限を予め 知ることはできない。したがって， $\mathrm{L}=\mathrm{SN}(0<\mathrm{s}<1)$ と置いて $\mathrm{s} 0.01 〜 0.5$ の範囲で適当に変化させなが ら検討を行ったが, 結果的に顕著な傾向を把握でき なかった。そこで,これらのスワップについてはc） 以前の試行実験で既に用いているL=0.1Nをそのまま 採用することとした。

スワップ3については, 繰り返し計算の各段階で 最大限 1 つの要素しかタブーリストに書き込まれな いことから，Nの大きさのいかんに拘わらずLミMと

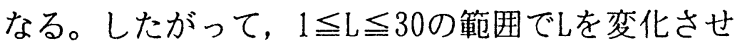

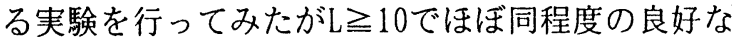
結果が得られたので，ここでは最終的に $\mathrm{L}=30(=M)$ と して与えることとした。

e ）繰り返し回数K,Mの決定

q, r, p, Lの值を既決定值に固定し，まずM= 30 と置 いてKを1〜20の範囲で適当に変化させてみたがスワ 
ップ1,2については10以上のKで，スワップ3では5以 上のKでほぼ同程度の良好な結果を生成することが 判明した。よって，スワップ1，2に対してはK=10を， スワップ3についてはK=5をそれぞれ採用することと した。

次に，このようにして決められたKに対して，Mを 10から50の間で変化させる実験を行ったが，スワッ プの種類によらずKミ30で結果の改善は飽和するこ とがわかった。よって，Mの值として30を採用する ことにした。

なお，d）およびe)の実験についてはノード数20と 300ネットワークに対しても実行したが得られた結 論に有意な差はなかった。

以上，開発した計算アルゴリズム実験の段階にお いて必要となる各種パラメータの与え方について述 べた。パラメータのあらゆる組み合わせについて網 羅的に調べてはいないので，本来の意味における最 適設定とはならないが，一応の良好な組み合わせの 候補の1つとしては位置づけられるであろう。以下 においては, これらのパラメータを使ってスワップ 操作種別相互の有効性比較とともに, 既開発のGAを 用いた方法との比較をとおした提案手法の有効性の 娭討を行う。

\section{（2）有効性の比較娭討}

ランダムに作成したノード数8, 20,30,38, 50,60, 700合計7つのネットワークについて，タブー探索 法でスワップ1を採用した方法（TABU1と略記），ス ワップ2を採用した方法（TABU2），スワップ3を採用 した方法（TABU3）および遺伝的アルゴリズムを用い た方法(GA)の4方法による計算結果を示すと表-1の ようになる。表中, 上段の数値は得られた目標関数 の最大値（正確には最良値）を表わしている。また， われわれの準備した計算プログラムでは，良好な代 替スケジュールも生成するという視点から, 計算途

表-1ノード数による TABU と GA の比較

\begin{tabular}{|c|c|c|c|c|c|c|c|}
\hline ノ-ド & 8 & 20 & 30 & 38 & 50 & 60 & 70 \\
\hline \multirow{2}{*}{ TABU 1 } & 0.7851 & 0.8085 & 0.5849 & 0.7850 & 0.7213 & 0.6868 & 0.7113 \\
\cline { 2 - 8 } & 0.5753 & 0.7957 & 0.5725 & 0.7677 & 0.7090 & 0.6588 & 0.7021 \\
\hline \multirow{2}{*}{ TABU 2 } & 0.7851 & 0.8074 & 0.6516 & 0.7615 & 0.7415 & 0.6504 & 0.6521 \\
\cline { 2 - 8 } & 0.6447 & 0.8016 & 0.6347 & 0.7460 & 0.7331 & 0.6446 & 0.6484 \\
\hline \multirow{2}{*}{ TABU 3 } & 0.7851 & 0.8402 & 0.6612 & 0.8215 & 0.8138 & 0.7611 & 0.7762 \\
\cline { 2 - 8 } & 0.6721 & 0.8350 & 0.6588 & 0.8209 & 0.8116 & 0.7609 & 0.7757 \\
\hline \multirow{2}{*}{ GA } & 0.7851 & 0.8097 & 0.6233 & 0.7449 & 0.7005 & 0.5838 & 0.7139 \\
\cline { 2 - 8 } & 0.6520 & 0.8066 & 0.6189 & 0.7385 & 0.6964 & 0.5834 & 0.7124 \\
\hline
\end{tabular}

中で得られる解を，目標関数の大きい順に10個記憶 しておくという方法を採っている。下段の数值はそ れら10個の目標関数の平均值である。

なお，GAにおける遺伝操作は既に行われた検討結 果をもとに ${ }^{8)}$, 淘汰としてはエリ一ト保存戦略を, 交差には一様交差を，交配には期待値戦略を，突然 変異には反転方式をそれぞれ採用するようにしてい る。

表-1より，まずTABUにおける 3 つスワップ操作 の有効性を調べてみると， スワップ1とスワップ2は 押しなべて同等の性能を有していることおよびスワ ップ3が最大值, 平均値ともに最も良好な結果を生 成していることがわかる。しかしながら, 計算時間 についてはノード数が38を越えたネットワークでは TABU1およびTABU2はいずれもTABU3の1/10〜1/20程 度となっており（計算機はHITAC M-860/60。TABU3 のCPU時間：ノード数 38 で約 100 秒, ノード数70で約 750 秒），この点での相対的有利性は持っている。

次に, 目標関数の改善の点で最も性能のよいTAB U3とGAの比較を行うことにより, 提案方法の有効性 を検証することとするが, その場合, 公平な比較条 件を整えるため，GAにおける計算繰り返し回数を意 味する世代数は, CPU時間がTABU3のそれとほぼ同程 度になるように設定した。なお，2方法間に必要記 憶容量上の有意な差はない。表から明らかなように ノード数8の最大值が同一である外はすべてTABU3の 結果の方が優れている。われわれが先に報告した時 点においては ${ }^{92}$ ，ノード数が多くなるとTABU3の対 GA優位性は崩れたが，今回の計算プログラム改良に よりこのような結果となっている。特に, 出発点と なるネットワークに対して付加アークを削除した効 果は顕著であった。なお，図-3はノード数38のネッ

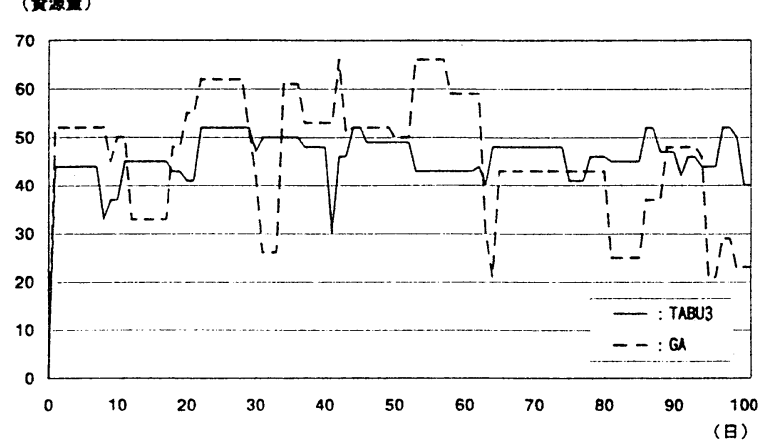

因-3 TABU3 とGA の山程み图比较 (ノート數 38) 


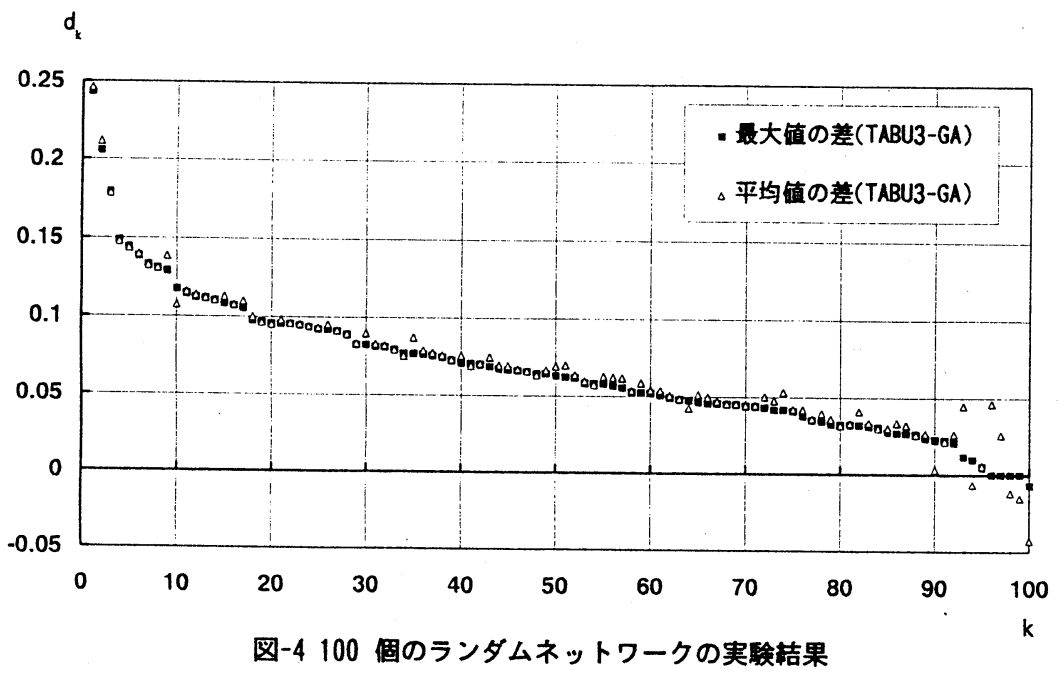

トワークについて, TABU3とGAで求められた最大解 の山積み図を示したものである。TABU3から得られ た山積み図の方のより滑らかな資源量変化傾向が明 らかに読み取れる。

GAについては世代数を多くとることにより，より 優秀な個体（この場合は良好なスケジュール）が発 生することが期待されるので, 念のために世代数を 10倍に増やした結果も求めてみた。しかしながら, 結局TABU3を蓤駕するまでには至らなかった。

上に述べた結果はあくまでも任意に選んだ7つの 初期ネットワークについてのみ言えることとも考え られるので，より一般性を志向すべく，われわれは 最後に100個のネットワークに対してGAとTABU3を適 用するという実験を行った。ネットワークはノード 数（=作業数）を8〜88, 作業 $\mathrm{i}$ の必要資源量 $\mathrm{a}_{\mathrm{i}}$ を2 19, 作業時間 $b_{i}$ を 5 23日の範囲でランダムに与え, ノード間のアークも一定の条件の下にランダムに生 成した。計算結果は図-4に示したとおりである。た だし， $\mathrm{d}_{\mathrm{k}}$ はk番目スケジュール問題に対してTABU3で 求めた目標関数とGAで求めた目標関数の差を表して いる。なお，kは最大値の $\mathrm{d}_{\mathrm{k}}$ の大きさの順に設けた 便宜的問題番号にすぎない。図より, 最大値の $\mathrm{d}_{\mathrm{k}}$ が 1つの問題を除きすべて非負の領域にプロットされ ていることが読み取れるが，このことは実験の対象 とした殆んど全てのネットワークについてTABU3の 方がより良好なスケジュールを発見していることを 意味している。

以上から, 本研究で提案したタブー探索法を用い た方法（スワップ3使用）はGAを用いた方法に比べ
て有効性が高いと結論づけられる。

5.おわりに

本研究では, タブ一探索法のマン・スケジューリ ング問題への適用に際して必須要件となる局所探索 技法すなわちスワップ操作とそれに付随するタブー リスト形成法について検討し，計算例の中でGAとの 比較をとおしてその有効性を調べた。その結果, 初 期ネットワークに対する付加候補リンクを逐次的に 調べ上げるという基本原則に則ったスワップ3を使 えば，安定的にGAを凌ぐ結果を生成することがわか った。

ここで示した方法はスケジューリングの複数の目 標を同時に考慮し得る点に 1 つ特徵を有している が，本稿ではその取り扱い方として加重和によるス カラ化手法を採用した。これによってパレート最適 解の 1 つが得られるが，多目標の扱い方は多様であ り，スケジューリングの方法としてはそうしたいろ いろな意思決定の要請に沿う形でのアルゴリズムの 弾力性を持っておいた方がよい。本研究で示した解 法（GAもそうであるが）は，幸いというべきか，い わゆる制約条件および目標関数を陽表的に考慮する 数理計画法ではなく，試行錯䛊的に解を探ってゆく 性質のものであるため, 計算プログラムの若干の手 直しにより，種々の多目標計画法の考え方にも対応 し得る。

今後の方向として，広域的探索に力のあるGAの長 所と局所探索を得意とするTABUを組み合わせ，さら 
に計算効率を向上させてゆくことが考えられるが， 現在までの試行ではあまりうまく行っていない。検 討をさらに深め, 将来的に稿を改めて発表したい。

\section{参考文献}

1)Huppe, B・奥谷 嚴 : マン・スケジューリング問 題における遺伝的アルゴリズムの適用性, 電気 学会論文誌C, Vol. 114-4, pp. 450-455, 1994.

2) 北野：遺伝的アルゴリズム, 産業図書,

3)須永：PERT系のプログラミング, 朝倉書店

4) Malek, M. et al:Serial and parallel simulated annealing and tabu sesrch algorithm for the travelling salesman problem, Annals of Operations Res., Vol.21, PP. 59-84, 1989
5)Glover, F. : Tabu search-Part I, ORSA J. on Computing, Vol. 1-3, PP. 190-206, 1989.

6)Glover, F. :Tabu search-Part II, ORSA J. on Computing, Vol. 2-1, PP. 4-32, 1990.

7)奥谷 篇・Huppe, B・福井紀行 : マンスケジュー リングにおけるタブー探索法の応用, SICE学術 講演会予稿集, PP. 681-682, 1994.

8)奥谷 䉷・加藤正高・福井紀行: マンスケジュー リングにおける遺伝的アルゴリズムの用い方, 土木学会中部支部講演概要集, IV-16, 1995.

9)奥谷 篇・福井紀行・風間克則：タブー探索法に よるマンスケジューリングの解法, 土木計画学 研究·講演集, No. 18(2), pp. 401-404, 1995.

\section{マン・スケジューリンクにおけるタブー探索法の適用性*}

奥谷 䈨**·福井紀行 ${ }^{* * *} \cdot$ 風間克則

本研究では，マン・スケジューリング問題に対するタブー探索法（TABU）の適用方法が示されいる。

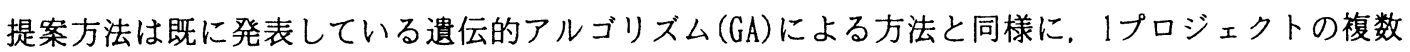
目標を同時に考虑し得るという特徵を持っている。アローダイヤグラムで表わされた初期スケジュ ールに対して，新しい追加アークを示すビット列によって代替スケジュールを表わし，アルゴリズ ムを適用できるようにしている。局所探索技法であるスワップ操作について3つの方法が検討され ているが，そのうちの最良のものを用いればGA法に比べて，より良好なスケジュールを生成し得る ことを,ノード数8〜88の100個のネットワークの計算例で実証している。

\section{Adaptability of Tabu Search in Man Scheduling Problem *}

\section{By Iwao OKUTANI ${ }^{* *} \cdot$ Noriyuki FUKUI ${ }^{* * *} \cdot$ Katunori KAZAMA}

To apply the tabu algorithms schedule alternatives are expressed in the form of string whose elements indicate variation of affixation patterns of new arcs placed on the study scheduling network. Three swap operations (local search operations) are proposed and widely tested. Like the previously publised scheduling method utilizing genetic algorithms (GA), the proposed method has ability to find the optimum schedule which attains multiple goals of the project economy. Experimental results with 100 scheduling problems involving 8 to 88 activities show that the tabu method employing the best swap operation consistently outperforms the GA method. 